\title{
GISMOWA: Geospatial Risk-Based Analysis Identifying Water Quality Monitoring Sites in Distribution Systems
}

Larsen, Sille Lyster; Christensen, Sarah Christine Boesgaard; Albrechtsen, Hans-Jørgen; Rygaard, Martin

Published in:

Journal of Water Resources Planning and Management

Link to article, DOI:

10.1061/(ASCE)WR.1943-5452.0000754

Publication date:

2017

Document Version

Peer reviewed version

Link back to DTU Orbit

Citation (APA):

Larsen, S. L., Christensen, S. C. B., Albrechtsen, H-J., \& Rygaard, M. (2017). GISMOWA: Geospatial Risk-

Based Analysis Identifying Water Quality Monitoring Sites in Distribution Systems. Journal of Water Resources Planning and Management, 143(6), [04017018]. https://doi.org/10.1061/(ASCE)WR.1943-5452.0000754

\section{General rights}

Copyright and moral rights for the publications made accessible in the public portal are retained by the authors and/or other copyright owners and it is a condition of accessing publications that users recognise and abide by the legal requirements associated with these rights.

- Users may download and print one copy of any publication from the public portal for the purpose of private study or research.

- You may not further distribute the material or use it for any profit-making activity or commercial gain

- You may freely distribute the URL identifying the publication in the public portal 


\section{NOTE: This is the accepted author manuscript. Numerous text-edits were made and several references corrected in the final published proof.}

\section{GISMOWA: Geospatial Risk-Based Analysis Identifying Water Quality Monitoring Sites in Distribution Systems}

Sille Lyster Larsen ${ }^{1}$; Sarah Christine Boesgaard Christensen, Ph.D. ${ }^{2}$; Hans-Jørgen Albrechtsen, Ph.D. ${ }^{3}$; and Martin Rygaard, Ph.D. ${ }^{4}$

${ }^{1}$ MSc.Eng., Department of Environmental Engineering, Technical University of Denmark, Bygningstorvet, building 115, 2800 Kongens Lyngby, Denmark, slyla@env.dtu.dk, ORCID: 0000-0001- 9356-4726

${ }^{2}$ HOFOR A/S, Ørestads Boulevard 35, 2300 København S, Denmark, sach@ hofor.dk. ORCID: 0000-0001-6183-6045

${ }^{3}$ Department of Environmental Engineering, Technical University of Denmark, Bygningstorvet, building 115, 2800 Kongens Lyngby, Denmark, hana@env.dtu.dk, ORCID: 0000-0003-3483-7709

${ }^{4}$ Department of Environmental Engineering, Technical University of Denmark, Bygningstorvet, building 115, 2800 Kongens Lyngby, Denmark, mryg@env.dtu.dk, ORCID: 0000-0001- 8578-8842 (corresponding author)

\section{Abstract}

Monitoring water quality in drinking water distribution systems is the base for pro-active approaches to prevent or manage emerging water quality issues, and such a monitoring requires a strategic selection of relevant and representative monitoring sites. GISMOWA is a new GIS and risk-based analysis tool to identify and to prioritise pipe segments for water quality monitoring and to comply with existing monitoring and sampling guidelines. The tool was designed to integrate multiple parameters categorized as 1) Hydraulic and structural weaknesses in the system, e.g. residence time, 2) External threats, e.g. contaminated sites, and 3) Sensitive consumers, e.g. hospitals in a GIS environment. The tool used a multi-criteria decision analysis to evaluate multiple monitoring site parameters and map zones particularly suitable for water quality monitoring. GISMOWA was applied to Danish water distribution systems as a transparent and simple-to-use tool which facilitated a complete overview of the distribution system, including sensitive consumers and consumers in general, and thus fulfilling a precondition for a HACCP-based monitoring strategy of drinking water.

\section{Introduction}

Over the last couple of decades risk management has become highly considered in water supply. In particular, the revision of the World Health Organization's (WHO) Guidelines for Drinking Water Quality 
(WHO, 2008) introduced a transition to an explicit risk management philosophy, with emphasis on applying risk frameworks and risk tools such as the HACCP approach (Hazard Analysis and Critical Control Point), originally developed by NASA and the food manufacturing industry. The aim of HACCP is to ensure an understanding of the drinking water system allowing operators to identify and prioritise the existing risks and to apply appropriate control measures to reduce risks to an acceptable level (Davison et al., 2005). The multiple-barrier principles of HACCP is adapted to the context of drinking-water through the implementation of WHO's “water safety plans” (Davison et al., 2005; WHO, 2008). Through this work on preventing waterborne outbreaks of diseases, attention is increasingly directed towards the distribution system (DS), due to its inherent vulnerability to both accidental and intentional contamination (Lindley and Buchberger, 2002). Over the past 36 years, approximately $10 \%$ of all reported contaminations within the DS in public water supplies in the United States were due to a deficiency in the DS (e.g. cross-connections, contamination of water mains or storage facility) (Craun et al., 2010). Between 1999 and 2002 the DS accounted for up to 50 $\%$ of waterborne outbreaks in community water systems (Blackburn et al., 2004; Lee et al., 2002). In Denmark, similar research specified $37 \%$ of the recorded contamination events between 2000 and 2002 as "unknown causes", and they were suspected to be caused by deficiencies in the DS (Engelsborg et al., 2009).

Extensive monitoring and documentation of water quality in the DS is therefore imperative to demonstrate compliance of the quality of the delivered drinking water with regulations, and if not, to act accordingly. Recent research has suggested to present real time water quality observations in a GIS environment and calls for integration of local knowledge (Yan et al., 2016; Behmel et al., 2016). This shows how (geo)graphical representation of safety and vulnerability status of DSs are considered increasingly important for securing drinking water quality. Regulations require that samples taken are "representative of water throughout the distribution system" (e.g. U.S. EPA, 1989) and guidelines exist to point to such locations (CDW, 2012; Kirmeyer et al., 2002; Livsmedelsverket, 2001; Miljøministeriet, 2005; NHMRC, 2011; U.S. EPA, 2014, 2007). However, the approaches to select monitoring locations are not explicitly defined and are rarely uniform among different nationalities. (Liu et al., 2012; Narasimhan et al., 2004; U.S. EPA, 2007). Water quality monitoring sites are often selected on an ad hoc basis, without considering the DS dynamics (Speight 
et al., 2009; Tryby and Uber, 2001). Several approaches have been suggested to establish strategic monitoring plans and to locate optimal monitoring sites which accommodate the structural diversity of DSs and display "representative water". Before the attacks on World Trade Center on September 11, 2001, the scientific literature focused on developing water quality monitoring programs to achieve regulatory compliance (Kumar, 1997; Lee and Deininger, 1992; Tryby and Uber, 2001). This was achieved using integer programming and greedy heuristic-based optimization algorithms focusing on hydraulic modeling of flow or water age. The events on September 11, gave rise to an additional monitoring focus, namely optimal placement of early warning detection systems (EWS) to identify intentional biological or chemical attacks (Ostfeld et al., 2008). The optimization methods used for identification of accidental or intentional contamination include stratified sampling (Speight et al., 2004) and numerous deterministic and stochastic optimization methods of one or few objectives such as detection likelihood, expected contaminated water volume and affected population (Berry et al., 2006; Krause et al., 2008; Liu et al., 2012; Ostfeld and Salomons, 2004; Preis and Ostfeld, 2008). The placement of sampling locations for detection of intentional attacks on the distribution system is largely based on an assumption that contamination can happen at any point and any time. This assumption of "equal risk" throughout the DS is not made for placement of routine sampling, which is in focus here.

In recent years, a subfield of the "sensor location problem" has developed, concerning non-ideal sensors and ensuring the detection of true-positives (Berry et al., 2007; Ohar et al., 2015; Perelman et al., 2012). GISbased data integration and analysis tools for monitoring site selection have been developed in parallel to advances in optimization algorithms. Research based on GIS tools has included development of methods to link historical water quality issues, such as positive coliform sampling, to the DS by network topologies and hydraulics (Besner et al., 2005, 2001; Furnass et al., 2013). Other studies have combined modelling of contaminant transport in saturated and unsaturated zones with pipe condition assessments in a GIS-based risk assessment (Sargaonkar et al., 2013; Vairavamoorthy et al., 2007). Populations at risk, sensitive consumers, hydraulics and water quality parameters were furthermore combined in a ranking procedure to locate monitoring sites in a DS (Bahadur et al., 2003; Lindley and Buchberger, 2002). 
This multi-objective approach is common to all the GIS-based research. The required mobilization and combination of existing DS related data reveals areas of particular vulnerability due to e.g. intrusion of external contaminants during pressure surges (Yang et al., 2011) or corrosion and microbial regrowth in e.g. pipes during conditions of slow water velocity (Nawrocki et al., 2010). The methods not only point out suitable monitoring sites according to multiple objectives, it also provides the utility with general knowledge of the DS complying with the HAACP approach. The mentioned GIS-based methods largely comply with Multi-Criteria Decision Analysis (MCDA), by transforming and combining geographical data and in some cases value judgments (the decision-maker's preferences) to obtain information for decision making (Malczewski, 2007). However, the above studies fail to combine all of the above mentioned parameters, using a consistent GIS-based MCDA approach, linking the decision process to national guidelines on representative water.

The overall aim of this study was to develop a holistic and systematic GIS and risk-based analysis tool to identify and prioritize pipe segments for monitoring water quality. This was achieved by three means: (1) Identify and describe water quality affecting parameters as well as groups of parameters exhibiting causal water quality affecting relationships, according to multiple national guidelines and scientific literature. (2) Mobilize existing data identified in (1), and (3) assess the combinations of suggested parameters, through a holistic and systematic MCDA-approach taking advantages of readily available tools from e.g. ArcGIS or other open source GIS-tools.

Depending on data availability and monitoring objective, the method supports decision makers in pointing out and evaluating overall suitability of sites for e.g. microbial contamination, chemical contamination, chlorine residuals, taste and odour issues or hydraulic failures, such as pressure losses. Both routine grab sampling as well as on-line monitoring sites can be appointed using the method, with accidental contamination events in focus. The approach was named GISMOWA, GIS-assisted MOnitoring of drinking WAter quality. 
The approach has been applied at three Danish water utilities to investigate the function and flexibility of the method and to evaluate how the method can be adjusted to suit different utilities, with different sets of data and modelling tools.

\section{Materials and Methods}

\section{Existing guidelines for monitoring in the DS}

In general, utilities establish a DS monitoring program to comply with regulatory requirements of monitoring and to document the required water quality everywhere in the DS. Based on the requirements, many countries have implemented guidelines on water quality monitoring (e.g. Health Canada, 2012, Livsmedelsverket, 2001, Miljøministeriet, 2005, NHMRC, 2011, U.S. EPA, 2014), with variations from country to country. The guidelines are generally divided into what is here defined as "locations" and "location features". Locations outline the physical location of a monitoring site, e.g. places of far distances from the water works, at dead ends, or where water is mixed from several sources. Location features define the frequency of monitoring e.g. fixed vs. random or seasonal monitoring and accessibility at the monitoring site. Locations and location features are further subdivided into "monitoring site categories" describing recommended monitoring sites in the DS (Table 1).

The categories, "storage", "critical locations" and "strategic locations" are the most common categories in recommendations for monitoring sites in the DS. Monitoring locations within the category "storage" can easily be identified by the responsible utility personnel. However, critical locations, such as pipe segments with low flow rates and strategic locations, such as pipe segments where water on average comes from multiple sources, are less straightforward to identify since they often describes the causal relationship between several factors affecting the water quality. The category "sensitive consumers" is not mentioned as often as "critical locations" and "strategic locations", but is nevertheless included in the study, since it is regarded as relevant to consider in the development of a comprehensive monitoring strategy. 


\section{Model formulation}

GISMOWA was developed using the systematic approach of GIS-based MCDA. MCDA involves identifying and choosing alternatives to find the best solution based on the different parameters and priorities. The method is suitable for addressing complex problems featuring high uncertainty, different forms of data, conflicting objectives, and complex physical and socioeconomic systems (Wang et al., 2009). Accordingly, many spatial decision problems, such as the selection of monitoring sites give rise to the GIS-based MCDA (Malczewski, 2007).

Suitability maps to identify monitoring sites for multiple objectives, such as microbial contamination or risk of intrusion was created by combining multiple input parameters in separate easily visualized maps. This was done in a GIS environment according to standardization of input parameters into a common scale and ranking or prioritization according to water quality influence or importance on a scale from "irrelevant" to "extremely suitable".

A six-step approach was used to identify monitoring sites (Fig. 1):

1) Identification of relevant monitoring sites and monitoring site parameters

2) Definition of monitoring site parameter value range

3) Projection of monitoring site parameters onto the DS

4) Reclassification of monitoring site parameters to make them numerically comparable

5) Computing of individual and combined suitability maps

6) Evaluation of selected monitoring sites

GISMOWA is based on the GIS software, ArcGIS 10.1, ESRI 2012. DTK/Map50 from GeoDanmark, the Danish National Survey and Cadastre and Danish municipalities was used to visualize results.

Identification of relevant monitoring sites and monitoring site parameters (Step 1) 
Monitoring site parameters may influence the quality of the water, such as locations with risk of cross-connections between the water supply system and external source of pollution, low maximum velocities and high water temperature as well as identified sensitive consumers, and they were identified and listed together (Table 2). The parameters were selected based on scientific literature and monitoring guidelines and sorted into three parameter types: Hydraulic and structural weaknesses, external threats and sensitivities. Hydraulic and structural weaknesses refer to parameters potentially causing a pathway for contaminants to enter the DS or causing a water quality issue from within the DS. External threats refer to an external source of contamination in connection with the DS, and sensitivities refer to consumers that are more susceptible to health problems caused by a drinking water contamination. In addition, parameters important to Danish utilities were included, such as areas with risk of flooding and areas suitable for monitoring water from the same source at two different sites (referred to as contaminant tracking zones). It is questionable whether the utilities will be able to gather data for all the monitoring site parameters. However, the method allows the user to exclude the non-available monitoring site parameters and down-prioritize monitoring site parameters with very uncertain data. It is therefore crucial that the user acknowledges the limitation of using e.g. highly skeletonized hydraulic models for pressure surges or water residence time for locating monitoring sites and considers this when using the method. Danish drinking water distribution is not chlorinated, and therefore disinfection residuals are not included in the parameter list, but can be added to the analysis in systems with disinfection.

\section{Definition of monitoring site parameter value range (Step 2)}

The monitoring site parameter value range defines the value range for each individual parameter according to a defined upper or lower boundary value and the corresponding minimum or maximum parameter value. The boundary values define upper and lower threshold for the relevance of the parameters. Using the example of maximum velocity, the parameter value range would go from the minimum parameter value, for example $0.0 \mathrm{~m} / \mathrm{s}$ to the upper boundary value of 
$0.4 \mathrm{~m} / \mathrm{s}$. Water velocities above $0.4 \mathrm{~m} / \mathrm{s}$ are considered irrelevant to monitor (Table 3 ). The monitoring site parameter value range will ultimately vary from DS to DS according to the minimum and maximum parameter value, however the value range offers an immediate overview of non-critical areas of the DS and a higher resolution of areas of concern.

The upper or lower boundary value for each parameter was determined based on literature.

\section{Projection of monitoring site parameters onto the DS (Step 3)}

Once identified, the parameters were collected from a wide variety of sources, e.g. output from the hydraulic model or pipe database used by the utility (Table 2). The hydraulic and water quality parameters were simulated using the modelling tool Aquis (Schneider Electric, 2015), but other tools such as EPANET (Rossman, 2000) can provide the same type of data. The simulations covered a typical seven day demand cycle to include multiple demand patterns, and the output comprised e.g. the maximum velocity, maximum residence time and average flow for each pipe in the network during the seven day period (Table 2). In some cases the hydraulic model included the complete DS and in other cases only the transport pipes and mains. All data were converted into geospatial vector data (i.e. feature class) either represented as polylines, polygons or points. Aquis provides an automatic conversion of simulation results into GIS read shape-files. To process data in path distance analysis, reclassification and weighted overlay analysis, most data needed conversion to raster format. Table 2 lists the tools used to pre-process the data for the following MCDA. Raster layers were created with a cell size of $1 \mathrm{x} 1$ meters, to represent the distribution system in sufficient detail.

Hydraulic parameters were integrated into the GIS workspace as polylines representing the DS. To make the point and polygon data coincide with the DS (on top of the line data from the hydraulic model), point data was moved to coincide with the line data based on connection through supply pipes, and polygon data e.g. flooded areas and contaminated sites, overlaying the line data was selected using select by location tools. Subsequently, both point- and polygon data 
were converted into line format. The path distance tool was applied to convert point/polygon data into a line-proxy, in which an output raster represents the line. Each cell in the raster was assigned the accumulative distance from the source cell to the closest point in question. By calculating the accumulative distance over the raster surface, the tool measures the least distance to reach a source, e.g. hospital, flooded area or sewage pipe. Polyline data, pipe age and pipe material are typically registered in a pipe database (e.g. CAD software). Inconsistencies in pipe location between the pipe database and the hydraulic model database were resolved by transferring attributes from the pipe database to the hydraulic model database using queries. When several pipe segments from one database overlapped one pipe segment from the other, maximum pipe age was used to define the entire segment to ensure that "old" pipes were pointed out in the analysis. Pipe material was registered in the hydraulic model and thus directly integrated into ArcGIS.

\section{Reclassification of monitoring site parameters to make them numerically comparable (Step}

\section{4)}

Uncertainty in the predictions of water quality is inherent to DS monitoring. The utility or investigating authority is seldom able to determine and validate the cause of a contamination event, such as positive coliform samples. It is therefore difficult to establish statistical correlations between parameters affecting water quality and a quantified impact (Furnass et al., 2013; Sadiq et al., 2010). However, to limit this uncertainty, an upper or lower boundary value was identified for each parameter to define the range at which the parameter is likely to constitute a water quality issue (Step 2).

In the MCDA, values of monitoring site parameters were converted by reclassification into a uniform "suitability" scale with a range from 1 to 9. The lower value is referring to 'irrelevant', and the higher value is referring to 'extremely suitable' for monitoring. A scale from 1 to 9 was used to convert floating-point values to integers to support ArcGIS-handling and to create a map 
for each parameter which is intuitively understood from a user perspective. By doing so, resolution was lost. However, each parameter was considered a result on its own, and for consistency it was kept at the same 9-step integer scale as the combined suitability maps. In further developments of the method, a higher resolution can be achieved by selecting a suitability range from e.g. 0 to 255 in integer or 0 to 1 in floating-point (see methods for standardization in GIS-based MCDA (Eastman, 1995; Voogd, 1983)). Reclassification included linear decreasing or increasing functions as described by Voogd (1983). As an example, a decreasing linear function was used for e.g. velocity, where a pipe segment with a 'very low' value meant 'extremely suitable for sampling' (9) and a 'high' value (i.e. outside the parameter value range) meant 'irrelevant for sampling' (1). Conversely, an increasing linear function was used for e.g. temperature where a 'high' value referred to 'suitable' and vice versa.

The ArcGIS "Reclassify" tool was used to convert all parameters into the suitability scale, with the option of assigning the entire value range outside the boundary value to the scale value of 1 . The tool allows the user to create a non-linear scaling manually using e.g. a sigmoid function or using quantile or natural breaks as seen fit. However reclassification is considered rather subjective until further statistical evidence is produced to support e.g. sigmoidal over linear functions, and it is thus up to the user to decide on specific reclassification strategy.

\section{Computing of individual and combined suitability maps (Step 5)}

For each individual parameter, a suitability map was created and visualized in ArcGIS. Because the raster layer (cell size $1 \mathrm{x} 1$ meter) of the DS was difficult to see for a big area, each layer was converted back to vector format, making the visualization straight forward.

The reclassified parameters were combined by weighted linear combination (Voogd, 1983), where each parameter was multiplied by a weight to represent its importance. The sum of weighted parameters at each pipe segment produced the combined suitability maps, with suitability defined as (Eq. 1): 
Suitability $=\sum w_{i} X_{i}$

where $w_{i}=$ weight assigned to parameter $i$ and $X_{i}=$ suitability/criterion score of parameter $i$

The weight assigns the degree of significance to a specific parameter. In this study, five sets of weights were defined: Contaminant tracking zones, mixing zones, intrusion, microbial regrowth and sensitive consumers. These five sets of weights were specifically selected to comply with several national guidelines to identify areas with "representative water" in strategic and critical locations and regarding sensitive consumers (Table 1). However, the combination of parameters and weights can be altered by the user to target local regulatory monitoring requirements. Creating five suitability maps instead of one overall map, gave weight to some parameters, while others were left out (i.e. weight $=0$ ). The parameters within each suitability map were given equal weight according to a subjective decision. However, it could be argued that risk of a contamination from outside the DS is close to nothing without a broken pipe or reduced pressure and so these two parameters should be assigned a greater weight. These decisions involve intangibles that need to be traded off and several approaches have been suggested in previous MCDA studies. Kabir et al. (2014) provides a review hereof. The Analytical Hierarchy Process (AHP) suggested by Saaty (1980) is the most widely applied method and is based on providing pairwise comparisons between alternatives and introduces the judgement of experts to derive priority scales. Although not applied here to maintain brevity, a user of GISMOWA may enhance the expert judgment on the decision of weights by the use of AHP or similar tools.

To produce the five combined suitability maps, the weighted linear combination was implemented in ArcGIS by the weighted overlay tool. The individual and combined suitability maps were then used to identify pipe segments suitable for water quality monitoring complying with existing guidelines.

\section{Evaluation of selected monitoring sites (Step 6)}


Once the pipes most suitable for monitoring were identified, selected sites within each pipe segment were evaluated according to the extent of the monitoring program, e.g. how many consumers were covered by the monitoring sites and likely flow paths. A geometric network consisting of nodes and pipes was built using user guides in ArcGIS (ESRI, 2016). The "Utility Network Analyst" tool, made it possible to track up- and downstream pathways for a specific site. Flow direction was based on simulation results from the hydraulic model using the maximum daily flow simulated at $7.00 \mathrm{am}$, however, any time of the day could be chosen to illustrate flow direction. To examine the number of "protected consumers" according to each monitoring site selection, consumers from the utility database were added to the ArcGIS model framework, using the "snap" tool to move consumers to overlap the DS.

\section{Application analysis of GISMOWA}

GISMOWA was applied on three utilities in Denmark: VCS Denmark (VandCenter Syd A/S), HOFOR (HOFOR A/S) and Aarhus Water (Aarhus Vand A/S). The Danish water supply is based on groundwater that receives simple treatment (aeration and biological rapid sand filtration) and the water is not disinfected before reaching the customers.

VCS Denmark provides 165,000 people in Odense with 9,300,000 $\mathrm{m}^{3}$ water per year, conveyed through 1,029 km pipe. The DS is divided into 15 pressure zones and has two elevated reservoirs $\left(40,000 \mathrm{~m}^{3}\right)$ and nine pump stations. The hydraulic and water quality parameters were simulated using the modelling tool Aquis (Schneider Electric, 2015). The model was based on on-line SCADA data and was designed for a 7-day period representing a "standard week", as defined by the utility. The hydraulic model of VCS Denmark included transport pipes and mains.

HOFOR is the largest utility in Denmark and covers the capital as well as several surrounding municipalities. GISMOWA was applied on the municipality of Albertslund supplied by HOFOR, supplying 28,000 residents with $1,439,200 \mathrm{~m}^{3}$ of water per year. The hydraulic and water quality 
model was set up in Aquis (Schneider Electric, 2015). The model included mains and supply pipes.

Aarhus Water produces about $16,000,000 \mathrm{~m}^{3}$ drinking water per year shared among 10 water works and distributed by $1,500 \mathrm{~km}$ pipe. GISMOWA was applied on a section of the supply system, as the hydraulic and water quality modelling of the system was divided into several models according to pressure zones. Aquis (Schneider Electric, 2015) was used to simulate hydraulic and water quality parameters including both mains and supply pipes. The results from VCS Denmark are presented in the following section.

\section{Results and discussion}

\section{Identification of relevant monitoring sites and monitoring site parameters (Step 1)}

In accordance with the identified monitoring site parameters (Table 2) all 15 parameters were computed and gathered for the study of VCS Denmark.

\section{Definition of monitoring site parameter value range (Step 2)}

The upper and lower boundary values define the value at which a parameter no longer poses a threat to the water quality or is irrelevant to a monitoring site. As an example, water temperatures in the DS above $15{ }^{\circ} \mathrm{C}$ are considered challenging in relation to microbial growth (Donlan, 1988; Dukan et al., 1996; Fransolet et al., 1985; LeChevallier et al., 1991). The lower boundary was set to $12{ }^{\circ} \mathrm{C}$ according to Danish guidelines (Miljø- og Fødevareministeriet, 2015) meaning that any measured water temperature below $12{ }^{\circ} \mathrm{C}$ was considered irrelevant to the analysis. An example of an upper boundary is the velocity where computed maximum water velocities above $0.4 \mathrm{~m} / \mathrm{s}$ were left out, since it is stipulated that velocities above $0.4 \mathrm{~m} / \mathrm{s}$ are sufficient to prevent accumulation of material within the pipe system, reducing the risk of discoloration and mixing with steady water (Nawrocki et al., 2010; Poças et al., 2013; Vreeburg and Boxall, 2007). Similar 
approaches were used to establish upper or lower boundary values for all other parameters (Table $3)$.

For parameters not specifically quantified in the scientific literature, boundary values were set by a conservative judgment of risk. However, the findings and definition of an upper or lower boundary value, made it possible to narrow down the search of a suitable monitoring site to locations outside "preferred conditions".

Keeping the same boundary values between several utilities furthermore allows for comparison.

\section{Projection of monitoring site parameters onto the DS (Step 3)}

The monitoring site parameters computed by the hydraulic model were given as line-features and represented the DS directly. The structure of the hydraulic model therefore defined the DS in the case of VCS Denmark. Converting the line-feature parameters from feature to raster introduced connections between pipes that in reality were not connected but crossing. Point- and polygon features, such as hospitals and contaminated sites, were converted into raster, using the same raster as input layer. The accumulative distance was therefore computed based on "fake" connections, which made the distance appear shorter due to the fake shortcut. This happened approximately 25 times in the DS of VCS Denmark corresponding to once per $40 \mathrm{~km}$ pipe. This is not considered a problem in the case of VCS Denmark since our evaluation of the selected monitoring sites verified that this type of error was not present near the selected monitoring sites. This, however, is relevant to check for during the evaluation of selected monitoring sites, especially in systems that include a finer grid of supply pipes.

\section{Reclassification of monitoring site parameters to make them numerically comparable (Step}

\section{4)}

A common suitability scale was applied to the diverse and dissimilar input parameters of VCS

Denmark before combining the parameters in an integrated MCDA (Table 4). 
The assumption of a linear relationship between suitability and parameter value can be challenging, e.g. in the case of pipe materials, because different materials have different life expectancies. E.g. in the city of Montreal, the maximum number of pipe breaks per $10 \mathrm{~km}$ was in pipes installed between 1963 and 1974 (unlined ductile iron) so the oldest pipes were not necessarily the most vulnerable, but rather the material determined the risk (Besner et al. 2001). Including age as a parameter, assuming that the age is a linear proxy for the risk of breaks is therefore an approximation. In the case of VCS Denmark there was no knowledge of critical pipe installation periods and the age was in this case used linearly. In other distribution systems it may be useful to combine pipe material and pipe age into one layer, to take the varying life expectancies of the different materials into account.

Additionally, assigning a suitability class implicitly assume a relative scaling of impact, meaning that a suitability of 8 should be twice as preferred as a suitability of 4 . The suitability class for one parameter should also have the same meaning as for another parameter e.g. a grid cell with suitability class 4 for temperature $\left(13.50-14.25^{\circ} \mathrm{C}\right)$ assumes the same impact on the water quality as a grid cell with suitability class 4 for velocity $(0.25-0.30 \mathrm{~m} / \mathrm{s})$. Classifying the parameters according to this suitability scheme, inherently constitute some uncertainty, but the method however visualises the varying suitability in a systematic manner and copes with it by giving the user of GISMOWA the option of applying more or less weight to specific parameters when several monitoring site parameters are combined. GISMOWA furthermore allows the user to reclassify parameters using a non-linear function, e.g. by applying expert judgement or through the realization of statistical data.

\section{Computing of individual and combined suitability maps (Step 5)}

Each parameter was mapped and visualised using ArcGIS according to suitability (Fig. 2), and then pipe segments vulnerable to loss of physical and hydraulic integrity were identified and sensitive consumers pinpointed. The suitability map provides the user with an overview of the entire DS and where in the DS each parameter is most important for the safety. 
The maps can be continuously updated as pipes are replaced, new temperatures measured etc.

Analysing the maps on an individual basis may however not reflect the complex behaviour of coinciding physical, chemical and biological processes. Also, it may be difficult to identify a few monitoring sites based on the 15 individual maps. The 15 individual maps can thus be considered additional information about the DS, for the utility to use in maintenance planning and HACCPstrategies. To account for concurrent effects and to identify sites where several parameters coincide, the parameters were aggregated according to the monitoring site groups defined based on existing guidelines (Table 1), leaving out some parameters (equal to weight $=0$ ) and using equal weights among the included parameters (Table 5). This resulted in five suitability maps for mixing zones, intrusion, microbial regrowth and sensitive consumers and a map displaying contaminant tracking zones for each of the nine water sources in VCS Denmark. The most suitable pipe segments for each suitability map were visualised in Fig. 3. The contaminant tracking zones are displayed separately (Fig. 4).

The suitability map for sensitive consumers yielded suitability classes up to 8 , whereas the microbial regrowth map and intrusion map had a maximum suitability class of 7 (Fig. 3). None of the overlay parameters resulted in pipe segments with a suitability class of 9 . The mixing zone map (Fig. 3A) showed one long pipe segment fed by four sources corresponding to a suitability class of 9. Comparing the selected monitoring sites with the contaminant tracking zones (Fig. 4), only one of the selected sites could be used to track a contamination event back to one specific source. However, it shows that during the daily supply situation $55 \%$ of the DS receives water from a single source (Fig. 4) making contaminant tracking possible in combination with one or more of the other parameters and groups characterising representative water according to guidelines (Table 1).

The resulting combined suitability maps showed that risk of intrusion and sensitive consumers were concentrated near the centre of the DS. This coincided with aging pipes and undesirable 
pipe material, contaminated sites and flooded areas (Fig. 2). On the contrary, areas with an elevated risk of microbial regrowth and with water mixed from several sources were located in the outskirts of the supply area, where longer residence time and low water velocity prevailed. The overall results tallied with predictions of such sensitivities and weaknesses in the DS, and the approach allowed specific segments to stand out for further investigation or monitoring.

Based on the combined suitability maps, $38 \mathrm{~km}$ suitable pipe segments of the $185 \mathrm{~km}$ DS (21\%) were identified for water quality monitoring, complying with existing guidelines for critical and strategic locations and sensitive consumers i.e. representative water (Fig. 3). Approximately 51 $\%$ of the selected sections represented the group "sensitive consumers", $26 \%$ "intrusion", $15 \%$ "mix" and $8 \%$ "microbial regrowth". In VCS Denmark, water was already sampled at waterworks and elevated storage reservoirs and the specific monitoring locations were therefore selected at other locations. With $38 \mathrm{~km}$ suitable pipe segments, local knowledge was applied to point out exact locations for monitoring according to e.g. accessibility. One monitoring location was selected for each combined suitability map (Fig. 3).

\section{Evaluation of selected monitoring sites (Step 6)}

Besides selecting suitable sites for monitoring representative water according to guidelines, each selected site was evaluated according to how many consumers were located downstream. Using a static flow pattern can be sufficient in DSs with one or few sources located in each end of the system, and when flow patterns are uniform and predictable. Static flow will however oversimplify the transport of a potential contaminant in a system with many sources and looped network structures. Due to the many sources of water in the DS of VCS Denmark, hydraulic modelling showed that up- and downstream flow conditions varied throughout the day. Changing the flow pattern from time of maximum demand $(7.00 \mathrm{am})$ to the time of min. demand $(04.00 \mathrm{am})$ would change the direction of flow in $31 \%$ of the pipes (results not shown). The selected monitoring sites were therefore located in a segment with unidirectional flow. 
The ArcGIS "Utility Network Analyst" tool was used to track up- and downstream pathways from the selected sites. A potential contamination event in a Danish DS would make up a risk for all downstream consumers, due to the distribution of groundwater using no disinfection residuals. Therefore, inclusion of a contaminant model simulation is not necessary to define the extent of a contamination at each site. By tracking the entire downstream system it was possible to account for the number of people potentially affected by a contamination through e.g. intrusion (Fig. 3).

8,686 consumers are located downstream the selected monitoring site according to the set of weights "intrusion". In comparison, 97,903 consumers are located downstream the monitoring site identified using the set of weights "sensitive consumers". Evaluating population as a parameter hence, visualises the compromise of choosing a monitoring site in a remote location versus one in the upstream or central part of the DS (Fig. 3).

\section{Applicability of GISMOWA}

The application of the method to several utilities in Denmark proves the easy applicability of GISMOWA to different DSs with different data availability. In some utilities the suitability maps can be based on all or the majority of parameters influencing the selection of a monitoring site, but other utilities only have few parameters to base the maps on. In VCS Denmark 15 parameters were included, in HOFOR 9 parameters were included, and in Aarhus Water it was possible to include 11 parameters. Hydraulic model extent also varies from utility to utility. Some include the entire DS while others only include transport pipes and mains, and subsequently the resulting suitability maps vary in degree of detail. Furthermore, the amount of known unknowns, such as closed valves and unregistered repaired pipes, and lack of on-site data makes the validation of the hydraulic model difficult. However, several parameters do not depend on the calibration of a hydraulic model, e.g. sensitivities and external threats, and these parameters may therefore be given higher suitability, in the selection of a suitable monitoring location. The flexibility of parameter usage is thus an advantage compared to complex computational algorithm approaches 
depending on calibrated hydraulic model. The flexible usage of parameters allows the user to modify the monitoring objective from e.g. Total Coliform Rule monitoring to taste and odor problems, by changing the parameters from temperature, residence time and velocity to pipe material (i.e. leaching) or disinfection residuals. Trépanier et al. (2006), used a similar integrated approach to develop a new GIS-based software to identify causes of water quality problems. This study, however, uses already available tools from a GIS-product, in combination with data projection onto the DS and weighted overlay analysis. For utilities already familiar with GISproducts, GISMOWA is easy to implement and results in an easily comprehendible overview of the DS, necessary when determining a monitoring strategy. Also, several new parameters were introduced and more data was integrated in this study compared to previous studies (Besner et al., 2005, 2001; Furnass et al., 2013; Sargaonkar et al., 2013; Trépanier et al., 2006; Vairavamoorthy et al., 2007; Wang et al., 2014). The use of MCDA in combination with local knowledge in the identification of monitoring sites has a major advantage since the users can apply their preferences with respect to parameter selection and ranking. This participation and understanding of the system generally help to enhance the confidence in the results, used for policy- and HACCP-development (Limayem and DeSanctis, 2000).

GISMOWA proved flexible and easily modifiable to suit the needs of the utilities in question. The mapping created a general overview of the DS and its users, which also is beneficial during an emergency situation. Also, the visualisation of vulnerable pipe segments can be used as decision support when placing on-line sensors or secondary hygienic barriers, such as UV, in the DS. During long periods of construction work, or during extreme rain events, the maps can be used to locate temporary monitoring sites to monitor for intruding water. The maps can be used to identify areas where seasonal monitoring is relevant, such as in summer home areas. Finally, the suitability maps, once produced, can be useful during emergency responses to contamination events, because they show potential hydraulic and structural weaknesses, external threats, and sensitivities present in the vicinity of the contamination. 
Until more research and better tools to determine the exact cause of contamination events are developed, it is challenging to reclassify and apply weights to parameters affecting water quality. The scope of our study was to suggest a method to narrow down the search area for critical pipe segments by identifying critical value ranges and applying weights according to causal relationship. However, the approach acknowledges and uses other criteria to influence the final selection of monitoring sites including local knowledge about the area e.g. accessibility. Further developments and implementation of the method could include sensitivity and uncertainty analyses that may reveal details on how the proposed reclassification and ranking affect the result. Some further limitations to GISMOWA relate to the dynamics of the analysis, such as diurnal flow variability when tracking up- and downstream flows. The lack of dynamic modeling can be addressed in future development of the method, but is until then accounted for by locating the monitoring sites in segments with unidirectional flow, like it was done in the analysis of VCS Denmark's DS. Along with increased availability of DS data additional layers can, depending on data type, be added to the analysis through point-, polygon- or line processing and continued MCDA evaluation.

\section{Conclusions}

Monitoring water quality in the DS at representative sites can be a challenging task to the utility and requires in-depth understanding of the system. The main objective of this study was to develop a holistic and systematic GIS and risk-based analysis tool to identify and prioritize pipe segments for monitoring water quality. The analysis is based on a wide range of factors and mechanisms affecting water quality as well as consumer sensitivities in the DS. Through multicriteria decision analysis, it was possible to visualise overlap of monitoring site parameters used to prioritise the monitoring efforts.

Suitability maps identified $21 \%$ of the DS of VCS Denmark which complied with international guidelines on representative water in the categories: Strategic locations, critical locations and 
sensitive consumers. Approximately $51 \%$ of the selected sections belonged to the group sensitive consumers, $26 \%$ to "intrusion", $15 \%$ to "mix" and $8 \%$ to "microbial regrowth". The results were consistent with the assumption of risk of microbial regrowth occurring on the outskirts of the DS, where temperatures were higher, velocities lower and general residence time longer. Risk of intrusion was prevailing near the city centre where the pipes were older and the risk of flooding greater e.g. due to combined sewers. The method facilitated the identification of pipe segments with elevated risk of impaired water quality or of particular sensitivity towards impaired quality, allowing the selection of monitoring sites.

Through this framework, planners are assured a visual, transparent and easy-to-implement concept in assessing the DS according to hydraulic and structural weaknesses, external threats and sensitivities. Furthermore the method assists planners with identifying and prioritising sites as part of the monitoring program since existing data are mobilized from several departments within a utility and from nationally available databases together with scientific literature forming an integrated risk assessment tool. By analysing the DS and mapping sensitivities, the method can document a selected monitoring strategy. The method therefore composes a significant aid to the overall risk management of the system - complying with the aim of a HACCP approach.

\section{Acknowledgements}

The project was a part of the innovation project "RiskStyr" and was funded by the partners and "Water in Urban Areas" under the Danish Agency for Science, Technology and Innovation. The project was a collaboration between Aarhus Water, HOFOR, VCS Denmark, DHI, the Nature Agency and the municipality of Odense. The authors wish to thank Erling Nissen for providing data from VCS Denmark, Kurt Brinkmann Kristensen for providing data from Aarhus Water and Søren Lind for providing data from HOFOR. Finally, the authors wish to thank students involved 
in the early development of GISMOWA: Thomas Grønkjær, Tina Bay Mathiesen, and Marie Lilian Høgild Færge. 


\section{References}

ArcGIS [Computer software]. ESRI, Redlands, CA.

Bahadur, R., Samuels, W. B., Grayman, W., Amstutz, D., and Pickus, J. (2003).

"PipelineNet: A model for monitoring introduced contaminants in a distribution system."

Proc., World Water Environment Resource Congress 2003, ASCE, Reston, VA.

Behmel, S., Damour, M., Ludwig, R., and Rodriguez, M. J. (2016). "Water quality

monitoring strategies: A review and future perspectives." Sci. Total Environ., 571, 13121329.

Berry, J., Carr, R. D., Hart,W. E., Leung, V. J., Phillips, C. A., andWatson, J.-P. (2007).

“On the placement of imperfect sensors in municipal water networks." Proc., 8th Annual

Water Distribution Systems Analysis Symp. (WDSA) 2006. ASCE, Reston, VA.

Berry, J., Hart, W. E., Phillips, C. A., Uber, J. G., and Watson, J.-P. (2006). "Sensor placement in municipal water networks with temporal integerprogramming models." $\mathrm{J}$.

Water Resour. Plann. Manage., 10.1061/(ASCE)0733-9496(2006)132:4(218), 218-224.

Besner, M. C., Gauthier, V., Barbeau, B., Millette, R., Chapleau, R., and Prévost, M. (2001). “Understanding distribution system water quality.”J. Am. Water Work. Assoc., 93(7), 101114.

Besner, M.-C., Gauthier, V., Trépanier, M., Leclair, M., and Prévost, M. (2005).

"Interactive analyser for understanding water quality problems in distribution systems."

Urban Water J., 2(2), 93-105.

Besner, M.-C., Prévost, M., and Regli, S. (2011). "Assessing the public health risk of microbial intrusion events in distribution systems: Conceptual model, available data, and challenges." Water Res., 45(3), 961-979. 
Blackburn, B. G., et al. (2004). "Surveillance for waterborne disease outbreaks associated with drinking water, United States, 2001-2002."

http://www.cdc.gov/mmwr/preview/mmwrhtml/ss5308a4.htm) (Apr.

23, 2015).

Craun, G. F. (2010). "Causes of outbreaks associated with drinking water in the United States from 1971 to 2006." Clin. Microbiol. Rev., 23(3), 507-528.

Danish EPA. (2005). Guidance to water quality and supervision of water supply plants, Danish Ministry of Environment, Copenhagen, Denmark (in Danish).

Danish EPA. (2015). Regulations on water quality and supervision of water supply plants, Danish Ministry of Environment and Food, Copenhagen, Denmark (in Danish).

Danva. (2012). Guidance in planning of drinking water control, DANVA guidance, Danish Water and Wastewater Association, Skanderborg, Denmark (in Danish).

Davison, A., et al. (2005). "Water safety plans: Managing drinking-water quality from catchment to consumer." Water, Sanitation and Health Protection and the Human Environment, World Health Organization, Geneva, 1-244.

De Moel, P. J., Verberk, J. Q. J. C., and Van Dijk, J. C. (2006). Drinking water: Principles and practices, World Scientific, Singapore.

Donlan, R. M., and Pipes, W. O. (1988). "Selected drinking-water characteristics and attached microbial-population density." J. Am. Water Work. Assoc., 80(11), 70-76.

Dukan, S., Levi, Y., Piriou, P., Guyon, F., and Villon, P. (1996). "Dynamic modelling of bacterial growth in drinking water networks." Water Res., 30(9), 1991-2002. 
Eastman, J. (1995). "Raster procedures for multicriteria multiobjective decisions." Photogramm. Eng. Remote Sens., 61(5), 539-547.

Engelsborg, C. C., Andersen, U. T., Albrechtsen, H.-J., Ethelberg, S., and Bagge, L. (2009). "Investigation of microbial drinking water contamination 2000-2002: Extent, causes, action and disease." Danish Ministry of the Environment, Copenhagen, Denmark (in Danish).

ESRI. (2016). “Create geometric network.” 〈http://goo.gl/tbo7WI〉 (Aug. 22, 2016).

Fransolet, G., Villers, G., and Masschelein,W. J. (2008). "Influence of temperature on bacterial development in waters." Ozone Sci. Eng., 7(3), 205-227. Furnass, W. R., Mounce, S. R., and Boxall, J. B. (2013). "Linking distribution system water quality issues to possible causes via hydraulic pathways." Environ. Model. Software, 40, 78-87.

Gullick, R. (2004). “Occurrence of transient low and negative pressures in distribution systems.” J. Am. Water Work. Assoc., 96(11), 52-66.

Gullick, R. (2005). “Application of pressure monitoring and modelling to detect and minimize low pressure events in distribution systems."

J. Water Supply Res. Technol. AQUA, 54(2), 65-81. Health Canada. (2012). "Guidelines for Canadian drinking water quality: Guideline technical document—Escherichia coli." Water, Air and Climate Change Bureau, Healthy Environments and Consumer Safety Branch, Health Canada, Ottawa.

Kabir, G., Sadiq, R., and Tesfamariam, S. (2013). "A review of multicriteria decisionmaking methods for infrastructure management." Struct. Infrastruct. Eng., 10(9), 11761210. 
Kirmeyer, G. J., et al. (2001). Pathogen intrusion into the distribution system, American Water Works Association, Denver. Kirmeyer, G. J. (2002). Guidance manual for monitoring distribution system water quality, American Water Works Association, Denver.

Krause, A., Leskovec, J., Guestrin, C., VanBriesen, J., and Faloutsos, C. (2008). "Efficient sensor placement optimization for securing large water distribution networks.” J. Water Resour. Plann. Manage., 10.1061/(ASCE)0733-9496(2008)134:6(516), 516-526.

Kumar, A., Kansal, M., and Arora, G. (1997). "Identification of monitoring stations in water distribution system.” J. Environ. Eng., 10.1061/(ASCE)0733-9372(1997)123:8(746), 746-752.

LeChevallier, M. W. (2004). Profiling water quality parameters: From source water to the household tap, American Water Work Association,Denver.

LeChevallier, M. W., Schulz, W., and Lee, R. G. (1991). "Bacterial nutrientsin drinking water." Appl. Environ. Microbiol., 57(3), 857-862. Lee, B., and Deininger, R. (1992). “Optimal locations of monitoring stations in water distribution system." J. Environ. Eng., 10.1061/(ASCE) 0733-9372(1992)118:1(4), 4-16.

Lee, S. H., Levy, D. A., Craun, G. F., Beach, M. J., and Calderon, R. L. (2002). "Surveillance for waterborne-disease outbreaks, United States, 1999-2000." 〈http://www.cdc.gov/mmwr/preview/mmwrhtml/ss5108a1.htm〉 (Apr. 23, 2015).

Limayem, M., and DeSanctis, G. (2000). "Providing decisional guidance for multicriteria decision making in groups.” Inf. Syst. Res., 11(4), 386-401.

Lindley, T. R., and Buchberger, S. G. (2002). "Assessing intrusion susceptibility in distribution systems.” J. Am. Water Work. Assoc., 94(6), 66-69.

Liu, S., Liu,W., Chen, J., andWang, Q. (2012). “Optimal locations of monitoring 
stations in water distribution systems under multiple demand patterns: A flaw of demand coverage method and modification." Front. Environ. Sci. Eng. China, 6(2), 204-212.

Livsmedelsverket. (2001). Guidance to drinking water regulations (SLVFS 2001:30) regarding drinking water, Livsmedelverket—National Food Agency, Uppsala, Sweden (in Swedish).

Malczewski, J. (2006). "GIS-based multicriteria decision analysis: A survey of the literature.” Int. J. Geogr. Inf. Sci., 20(7), 703-726.

Narasimhan, R., Brereton, J., Abbaszadegan, M., Alum, A., and Ghatpande, P. (2004). Sample collection procedures and locations for bacterial compliance monitoring, American Water Works Association, Denver.

Nawrocki, J., Raczyk-Stanisławiak, U., Swietlik, J., Olejnik, A., and Sroka, M. J. (2010). “Corrosion in a distribution system: Steady water and its composition." Water Res., 44(6), 1863-1872.

NHMRC, NRMMC (National Health and Medical Research Council, National Resource Management Ministerial Council). (2011). “Australian drinking water guidelines paper 6 national water quality management strategy." Commonwealth of Australia, Canberra, Australia.

Nygård, K., et al. (2007). "Breaks and maintenance work in the water distribution systems and gastrointestinal illness: A cohort study.” Int. J. Epidemiol., 36(4), 873-880.

Ohar, Z., Lahav, O., and Ostfeld, A. (2015). “Optimal sensor placement for detecting organophosphate intrusions into water distribution systems." Water Res., 73, 193-203. 
Ostfeld, A., et al. (2008). "The battle of the water sensor networks (BWSN): A design challenge for engineers and algorithms." J. Water Resour. Plann. Manage., 10.1061/(ASCE)0733-9496(2008)134:6(556), 556-568.

Ostfeld, A., and Salomons, E. (2004). "Optimal layout of early warning detection stations for water distribution systems security.” J. Water Resour. Plann. Manage., 10.1061/(ASCE)0733-9496(2004)130:5(377), 377-385.

Palleti, V. R., Narasimhan, S., Rengaswamy, R., Teja, R., and Bhallamudi, S. M. (2016). "Sensor network design for contaminant detection and identification in water distribution networks." Comput. Chem. Eng., 87, 246-256.

Perelman, L., Arad, J., Housh, M., and Ostfeld, A. (2012). "Event detection in water distribution systems from multivariate water quality time series." Environ. Sci. Technol., 46(15), 8212-8219.

Poças, A. (2013). "Methodology for sampling drinking water discolouration loose deposits at low velocities." Water Sci. Technol. Water Supply, 13(4), 1116-1122.

Preis, A., and Ostfeld, A. (2008). "Multiobjective contaminant sensor network design for water distribution systems.” J. Water Resour. Plann. Manage., 10.1061/(ASCE)07339496(2008)134:4(366), 366-377.

Rossman, L. A. (2000). “EPANET 2 users manual.” U.S. Environmental Protection Agency, Cincinnati.

Saaty, T. L. (1980). The analytic hierarchy process, McGraw-Hill,New York.

Sadiq, R., Kleiner, Y., and Rajani, B. (2010). "Modelling the potential for water quality failures in distribution networks: Framework (I).”J. Water Supply Res. Technol., 59(4), 255-276. 
Sargaonkar, A., Kamble, S., and Rao, R. (2013). "Model study for rehabilitation planning of water supply network." Comput. Environ. Urban Syst., 39, 172-181.

Schneider Electric. (2015). "Aquis.” 〈http://www.schneider-electric.com/〉 (Apr. 20, 2015).

Speight, V., et al. (2009). Probabilistic modeling framework for assessing water quality sampling programs, Water Research Foundation, Denver.

Speight, V. L., Kalsbeek, W. D., and DiGiano, F. A. (2004). "Randomized stratified sampling methodology for water quality in distribution systems.” J. Water Resour. Plann. Manage., 10.1061/(ASCE)0733-9496(2004)130:4(330), 330-338.

Tamminen, S., Ramos, H., and Covas, D. (2008). "Water supply system performance for different pipe materials. Part I: Water quality analysis."

Water Resour. Manage., 22(11), 1579-1607.

Teunis, P. F. M., Xu, M., Fleming, K. K., Yang, J., Moe, C. L., and Lechevallier, M. W. (2010). "Enteric virus infection risk from intrusion of sewage into a drinking water distribution network." Environ. Sci. Technol., 44(22), 8561-8566.

Trépanier, M., Gauthier, V., Besner, M., and Prévost, M. (2006). “A GIS-based tool for distribution system data integration and analysis.” J. Hydroinf., 8(1), 13-24.

Tryby, M., and Uber, J. (2001). "Representative water quality sampling in water distribution systems." Bridging the Gap: Meeting the World's Water and Environmental Resources Challenges, Proc., ASCE Annual Conf. on Water Resources Planning and Management, ASCE, Reston, VA, 1-10.

USEPA (U.S. Environmental Protection Agency). (1989). "Drinking water: National primary drinking water regulations.” Washington, DC. USEPA (U.S. Environmental 
Protection Agency). (2002). "Effects of water age on distribution system water quality." Washington, DC.

USEPA (U.S. Environmental Protection Agency). (2007). "A review of distribution system monitoring strategies under the total coliform rule." Washington, DC.

USEPA (U.S. Environmental Protection Agency). (2014). "The revised total coliform rule (RTCR) state implementation guidance." Washington, DC.

Vairavamoorthy, K., Yan, J., Galgale, H. M., and Gorantiwar, S. D. (2007). "IRA-WDS: A GIS-based risk analysis tool for water distribution systems.” Environ. Model. Software, 22(7), 951-965.

Voogd, J. H. (1983). Multicriteria evaluation for urban and rural planning, Delft, Netherlands.

Vreeburg, J. H. G., and Boxall, J. B. (2007). "Discolouration in potable water distribution systems: A review." Water Res., 41(3), 519-529.

Walter, R. K., Lin, P. H., Edwards, M., and Richardson, R. E. (2011). "Investigation of factors affecting the accumulation of vinyl chloride in polyvinyl chloride piping used in drinking water distribution systems." Water Res., 45(8), 2607-2615.

Wang, J.-J., Jing, Y.-Y., Zhang, C.-F., and Zhao, J.-H. (2009). “Review on multi-criteria decision analysis aid in sustainable energy decision-making." Renewable Sustainable Energy Rev., 13(9), 2263-2278.

Wang, Z., Devine, H., Zhang, W., and Waldroup, K. (2014). "Using a GIS and GIS-assisted water quality model to analyze the deterministic factors for lead and copper corrosion in drinking water distribution systems.” J. Environ. Eng., 10.1061/(ASCE)EE.19437870.0000816,4014004. 
WHO. (1997). Guidelines for drinking-water quality, 2nd Ed., World Health Organization, Geneva.

WHO. (2008). Guidelines for drinking-water quality, 3rd Ed., World Health Organization, Geneva.

WHO. (2014). Water safety in distribution systems, World HealthOrganization, Geneva.

Winther, L., Linde, J. J., andWinther, H. (2010). Water supply engineering,5th Ed., Polyteknisk Forlag, Lyngby, Denmark (in Danish).

Yan, W., Li, J., and Bai, X. (2016). "Comprehensive assessment and visualized monitoring of urban drinking water quality." Chemom. Intell. Lab. Syst., 155, 26-35.

Yang, J., LeChevallier, M. W., Teunis, P. F. M., and Xu, M. (2011). "Managing risks from virus intrusion into water distribution systems due to pressure transients.” J. Water Health, 9(2), 291-305. 
Table 1 Recommended locations and location features for monitoring drinking water quality in distribution systems from a variety of guidelines.

\begin{tabular}{|c|c|c|c|c|c|c|c|c|c|c|}
\hline \multirow[b]{2}{*}{ Type } & \multirow[b]{2}{*}{ Category } & \multirow[b]{2}{*}{ Description } & \multicolumn{7}{|c|}{ International guidelines } & \multirow{2}{*}{$\begin{array}{l}\text { Sum of } \\
\text { guidelines } \\
(\text { sum }=7)\end{array}$} \\
\hline & & & $\begin{array}{l}\text { Danish } \\
\text { EPA } \\
(2005)\end{array}$ & $\begin{array}{l}\text { DANVA } \\
(2012)\end{array}$ & $\begin{array}{l}\text { CDW } \\
(2012)\end{array}$ & $\begin{array}{l}\text { NHMRC } \\
(2011)\end{array}$ & $\begin{array}{l}\text { Kirmeyer } \\
\text { et al. } \\
(2002)\end{array}$ & $\begin{array}{l}\text { WHO } \\
\text { (1997; } \\
2014)\end{array}$ & $\begin{array}{l}\text { Livsmedelsverket } \\
\quad(2001)\end{array}$ & \\
\hline \multirow{4}{*}{ Location } & Storage & $\begin{array}{l}\text { Locations where water originates from or is stored in the network, } \\
\text { i.e. waterworks, service reservoirs or tanks. }\end{array}$ & + & + & + & + & + & + & - & 6 \\
\hline & $\begin{array}{l}\text { Strategic } \\
\text { locations }\end{array}$ & $\begin{array}{l}\text { Locations distributed throughout the whole water distribution } \\
\text { network, so that a large part of the DS is represented by monitoring. } \\
\text { Locations where water is mixed from several sources. } \\
\text { Locations where a contamination can be tracked, e.g. through } \\
\text { parallel monitoring, where one sample is taken at a storage unit and } \\
\text { another sample is taken somewhere in the DS where the water } \\
\text { originates from same source. }\end{array}$ & + & + & + & + & + & + & - & 6 \\
\hline & $\begin{array}{l}\text { Critical } \\
\text { locations }\end{array}$ & $\begin{array}{l}\text { Locations in the water distribution network, with e.g. long } \\
\text { residence times, low flowrates or blind ends. }\end{array}$ & + & + & + & + & + & + & - & 6 \\
\hline & $\begin{array}{l}\text { Sensitive } \\
\text { consumers }\end{array}$ & $\begin{array}{l}\text { Locations where many citizens are supplied. } \\
\text { Locations where a contamination could have a major impact, e.g. at } \\
\text { hospitals, nursing homes, production companies or schools. }\end{array}$ & - & + & - & - & + & + & - & 3 \\
\hline \multirow{4}{*}{$\begin{array}{l}\text { Location } \\
\text { feature }\end{array}$} & $\begin{array}{l}\text { Fixed } \\
\text { locations }\end{array}$ & Fixed monitoring, to establish water quality baseline data over time. & - & + & + & + & - & + & + & 5 \\
\hline & $\begin{array}{l}\text { Random } \\
\text { locations }\end{array}$ & Random monitoring, to cover a greater geographical area. & + & - & + & - & - & + & + & 4 \\
\hline & $\begin{array}{l}\text { Seasonal } \\
\text { locations }\end{array}$ & $\begin{array}{l}\text { Seasonal monitoring, to take into account variations in seasonal. } \\
\text { demand and water quality }\end{array}$ & - & + & - & - & + & - & - & 2 \\
\hline & $\begin{array}{l}\text { Accessible } \\
\text { locations }\end{array}$ & Accessibility, 24 hours a day. & - & + & - & - & + & - & - & 2 \\
\hline
\end{tabular}


Table 2 Monitoring site parameters identified as hydraulic and structural weaknesses, external threats and sensitivities, for general water distribution systems.

\begin{tabular}{|c|c|c|c|c|}
\hline Parameter type & Parameter & Data source* & Feature class & Pre-processing \\
\hline \multirow{8}{*}{$\begin{array}{l}\text { Hydraulic and } \\
\text { structural } \\
\text { weaknesses }\end{array}$} & Mixing zones ${ }^{\mathrm{b}}$ & Hydraulic model (average flow) & Line & Polyline to Raster \\
\hline & Contaminant tracking zones & Hydraulic model (average flow) & Line & Polyline to Raster \\
\hline & Velocity & Hydraulic model (max. velocity) & Line & Polyline to Raster \\
\hline & Pressure $^{\mathrm{a}, \mathrm{b}, \mathrm{c}, \mathrm{d}}$ & Hydraulic model (min. pressure) & Line & Polyline to Raster \\
\hline & Residence time $^{\mathrm{a}, \mathrm{b}, \mathrm{d}}$ & Hydraulic model (max. residence time) & Line & Polyline to Raster \\
\hline & Temperature ${ }^{\mathrm{a}, \mathrm{b}, \mathrm{d}}$ & Measured data (max. temperature) & Point & IDW, Extract by mask \\
\hline & Pipe age $\mathrm{e}^{\mathrm{a}}$ & Pipe database (max. age) & Line & Polyline to Raster \\
\hline & Pipe material $^{\mathrm{a}}$ & Pipe database & Line & Polyline to Raster \\
\hline \multirow{4}{*}{ External threats } & Contaminated sites $^{\mathrm{c}}$ & Portal for environmental data acquisition & Polygon & jelect by location, path distance \\
\hline & Flooded areas & The Danish geo data agency/Utility & Polygon & Select by location, path distance \\
\hline & Cross-connections $\mathrm{s}^{\mathrm{b}, \mathrm{c}, \mathrm{d}}$ & Municipality/Utility & Point & KML to layer, snap, pathdistance \\
\hline & Pressurised wastewater pipes ${ }^{\mathrm{c}}$ & Pipe database & Line & Snap, select by location, path distance \\
\hline \multirow{4}{*}{ Sensitivities } & Hospitals $^{\mathrm{c}, \mathrm{d}}$ & Municipality/Utility/Google & Point & KML to layer, snap, pathdistance \\
\hline & Nursing homes ${ }^{\mathrm{c}, \mathrm{d}}$ & Municipality/Utility/Google & Point & KML to layer, snap, pathdistance \\
\hline & Production companies & Municipality/Utility/Google & Point & KML to layer, snap, pathdistance \\
\hline & Population density ${ }^{\mathrm{c}, \mathrm{d}}$ & Municipality/Utility & Point & Snap \\
\hline
\end{tabular}

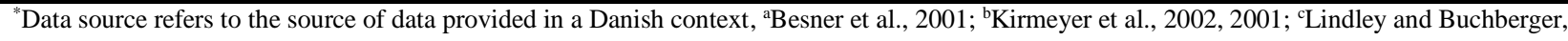
2002; ${ }^{\mathrm{d} B a h a d u r ~ e t ~ a l ., ~} 2003$ 
Table 3 Monitoring site parameters, their corresponding upper and lower boundary values, how they are defined and the reference.

\begin{tabular}{lll}
\hline $\begin{array}{l}\text { Monitoring site } \\
\text { parameter }\end{array}$ & $\begin{array}{l}\text { Upper }(<) \text { and lower }(>) \\
\text { boundary value }\end{array}$ & Definition of monitoring site parameter \\
\hline
\end{tabular}

Computed average water contribution from each source in the DS according to the simulation period. If the contribution from a source is

Mixing zones $\quad<95 \%$ water from same source more than $95 \%$ it is categorized as the sole supplier and mixing is assumed neglible. If the contribution is less than $95 \%$ the water is mixed from at least two different sources.

Contaminant tracking zones

$>95 \%$ water from same source

Computed average water contribution from each source in the DS according to the simulation period. If the contribution from a source is more than $95 \%$ it is assumed to be the sole supplier and water can be tracked back to that particular source.

A velocity of at least $0.4 \mathrm{~m} / \mathrm{s}$ is stipulated as being sufficient to prevent accumulation of material within the pipe system, reducing the risk of

Velocity

$$
<0.4 \mathrm{~m} / \mathrm{s}
$$

Pressure

$$
<196 \mathrm{kPa}
$$

Residence time

$>48$ hours

Temperature $\quad>12 \mathrm{C}^{\circ}$

Pipe age

$>25$ years

Pipe material

Not defined

Pressurised

wastewater pipes

$<5 \mathrm{~m}$ from DS

Contaminated sites

Flooded areas

$<5000$ m from site

Cross-connections

$<5000 \mathrm{~m}$ from flood

Hospitals

$<5000 \mathrm{~m}$ from building

$<5000$ m from hospital discoloration and mixing with steady water. Maximum velocity is used to identify pipe segments where the water never flows fast enough for self-cleaning. Computed maximum water velocities above $0.4 \mathrm{~m} / \mathrm{s}$ are left out.

Several studies discuss the issues of intruding water, due to low or negative internal water pressure. Due to limited data on the subject and the case-dependent nature of the problem, it is difficult to quantify 1) at which pressure level is it a problem and 2) how big is the problem. To define an upper boundary value, the recommended minimum pressure level above ground $196 \mathrm{kPa}(138-245 \mathrm{kPa})^{\mathrm{a}}$ was used as a conservative estimate. Computed minimum water pressure was used.

Residence time affects water quality indirectly, as water quality deteriorating factors are time dependent. Water is considered old when the residence time exceeds three days. In Denmark, water supply is based on groundwater and no disinfection residual is added to the water. The lower boundary value for this parameter was therefore conservatively defined to 48 hours. Residence time is the average water age simulated using the hydraulic model.

Water temperatures in the DS above $15 \mathrm{C}^{\circ}$ exhibit significantly higher microbial growth than at lower temperatures. In Denmark, the statutory order recommends water temperatures of maximum $12 \mathrm{C}^{\circ}$ at the consumer tap. The lower boundary was therefore conservatively set to $12 \mathrm{C}^{\circ}$.

Pipe age acts an indicator of structural vulnerability of the DS and several studies deal with the deterioration (ageing) of water mains and related risk of main breaks. The life expectancy of different pipe materials varies from 50 to 100 years. The lower boundary value was set to the half-life of the material with the lowest life expectancy, disregarding the variation in life expectancy.

Pipe material acts as an indicator of structural vulnerability of the DS due to its structural property and historical track record of breaking. Also certain pipe material show elevated risk of the release of problematic chemicals into the water. Depending on the focus of the monitoring strategy, break rate or release of chemicals according to material can define the classification of materials. No numerical boundary value is defined.

Research is increasingly dealing with the threat of drinking water contamination from sewage pipes in the vicinity of the drinking water DS. To account for the risk of pathogen intrusion during low pressure or pressure transient events and a potential leakage, the utility sewage database was used to locate sewage pipes within $5 \mathrm{~m}$ of the DS. Pressurised wastewater pipes more than $5 \mathrm{~m}$ away from the DS was left out.

Point and polygon features identify specific areas of interest to the monitoring program. Using the average water velocity of VCS Denmark $(0.12 \mathrm{~m} / \mathrm{s})$ and a 12 hour residence time resulted in a maximum distance of $5000 \mathrm{~m}$. Pipe segments more than $5000 \mathrm{~m}$ from point of interest was therefore left out.

\section{No reference}

\section{No reference}

Nawrocki et al., 2010; Poças et al., 2013; Vreeburg and Boxall, 2007

Gullick, 2005, 2004; Kirmeyer et al., 2001; LeChevallier et al., 2004; Moel, 2007; Winther et al., 2010

Sadiq et al., 2010; U.S. EPA, 2002

Donlan, 1988; Dukan et al., 1996; Fransolet et al., 1985; LeChevallier et al., 1991; Danish EPA, 2014

Besner et al., 2001; Sadiq et al., 2010;

Tamminen et al., 2008

Besner et al., 2001; Walter et al., 2011

Besner et al., 2011; Nygård et al., 2007; Teunis et al., 2010

No reference 
Table 4 Overview of the monitoring site parameters from VCS Denmark and the reclassification onto the suitability scale.

\begin{tabular}{|c|c|c|c|c|c|c|c|c|}
\hline \multicolumn{8}{|c|}{ Monitoring site parameter } & \multirow{2}{*}{$\begin{array}{c}\text { Suitability } \\
\text { class }\end{array}$} \\
\hline $\begin{array}{l}\text { Velocity } \\
(\mathrm{m} / \mathrm{s})\end{array}$ & $\begin{array}{l}\text { Pressure } \\
\quad(\mathrm{kPa})\end{array}$ & $\begin{array}{l}\text { Residence time } \\
\text { (days) }\end{array}$ & $\begin{array}{c}\text { Temperature } \\
\left({ }^{\circ} \mathrm{C}\right)\end{array}$ & $\begin{array}{l}\text { Pipe age } \\
\text { (years) }\end{array}$ & Pipe material & $\begin{array}{c}\text { Mix } \\
\text { (No. of sources) }\end{array}$ & Point-data $(\mathrm{m})^{a}$ & \\
\hline $0.00-0.05$ & $15-39$ & $11.6-13.0$ & $17.3-18.0$ & $104-115$ & Cast iron & 4 & $0-625$ & 9 \\
\hline $0.05-0.10$ & $39-62$ & $10.3-11.6$ & $16.5-17.3$ & $93-104$ & Asbestos cement & 3 & $625-1250$ & 8 \\
\hline $0.10-0.15$ & $62-86$ & $8.9-10.3$ & $15.8-16.5$ & $81-93$ & PVC & 2 & $1250-1875$ & 7 \\
\hline $0.15-0.20$ & 86-109 & $7.5-8.9$ & $15.0-15.8$ & $70-81$ & PE & - & $1875-2500$ & 6 \\
\hline $0.20-0.25$ & $109-132$ & $6.1-7.5$ & $14.3-15.0$ & $59-70$ & ProFuse (PE) & - & $2500-3125$ & 5 \\
\hline $0.25-0.30$ & $132-156$ & $4.8-6.1$ & $13.5-14.3$ & $48-59$ & Concrete & - & $3125-3750$ & 4 \\
\hline $0.30-0.35$ & $156-179$ & $3.4-4.8$ & $12.8-13.5$ & $36-48$ & Ductile iron & - & $3750-4375$ & 3 \\
\hline $0.35-0.40$ & 179-196 & $2.0-3.4$ & $12.0-12.8$ & $25-36$ & $\begin{array}{c}\text { Ductile iron (PE } \\
\text { encasement) }\end{array}$ & - & $4375-5000$ & 2 \\
\hline$>0.40^{b}$ & $>196^{b}$ & $<2.0^{\mathrm{b}}$ & $<12.0^{\mathrm{b}}$ & $<25^{b}$ & $\begin{array}{c}\text { Bonna (concrete } \\
\text { encasement) }\end{array}$ & 1 & $>5000^{b}$ & 1 \\
\hline
\end{tabular}

${ }^{a}$ Point data refers to the parameters given as either point- or polygon data and which are analysed using the path distance tool. b Refers to the boundary value defined in Table 5 . 
Table 5 Monitoring site parameters from VCS Denmark grouped according to categories selected from existing guidelines on finding representative water (section 2.1).

\begin{tabular}{lccccc}
\hline & \multicolumn{5}{c}{ Sets of weights (\%) } \\
\cline { 2 - 6 } Monitoring site parameter & Mixing zones & Intrusion & Microbial regrowth & Sensitive consumers & Contaminant tracking zones \\
\hline Contaminant tracking zones & 0 & 0 & 0 & 0 & 100 \\
Mixing zones & 100 & 0 & 0 & 0 & 0 \\
Velocity & 0 & 0 & 33.3 & 0 & 0 \\
Pressure & 0 & 14.3 & 0 & 0 & 0 \\
Residence time & 0 & 0 & 33.3 & 0 & 0 \\
Temperature & 0 & 0 & 33.3 & 0 & 0 \\
Contaminated sites & 0 & 14.3 & 0 & 0 & 0 \\
Flooded areas & 0 & 14.3 & 0 & 0 & 0 \\
Cross-connections & 0 & 14.3 & 0 & 0 & 0 \\
Pipe age & 0 & 14.3 & 0 & 0 & 0 \\
Pipe material & 0 & 14.3 & 0 & 0 & 0 \\
Pressurised wastewater pipes & 0 & 14.3 & 0 & 0 & 0 \\
Hospitals & 0 & 0 & 0 & 33.3 & 0 \\
Nursing homes & 0 & 0 & 0 & 33.3 & 0 \\
Production companies & 0 & 0 & 0 & 33.3 & 100 \\
\hline Sum & 100 & 100 & 100 & 00 \\
\hline
\end{tabular}




\section{Figures}

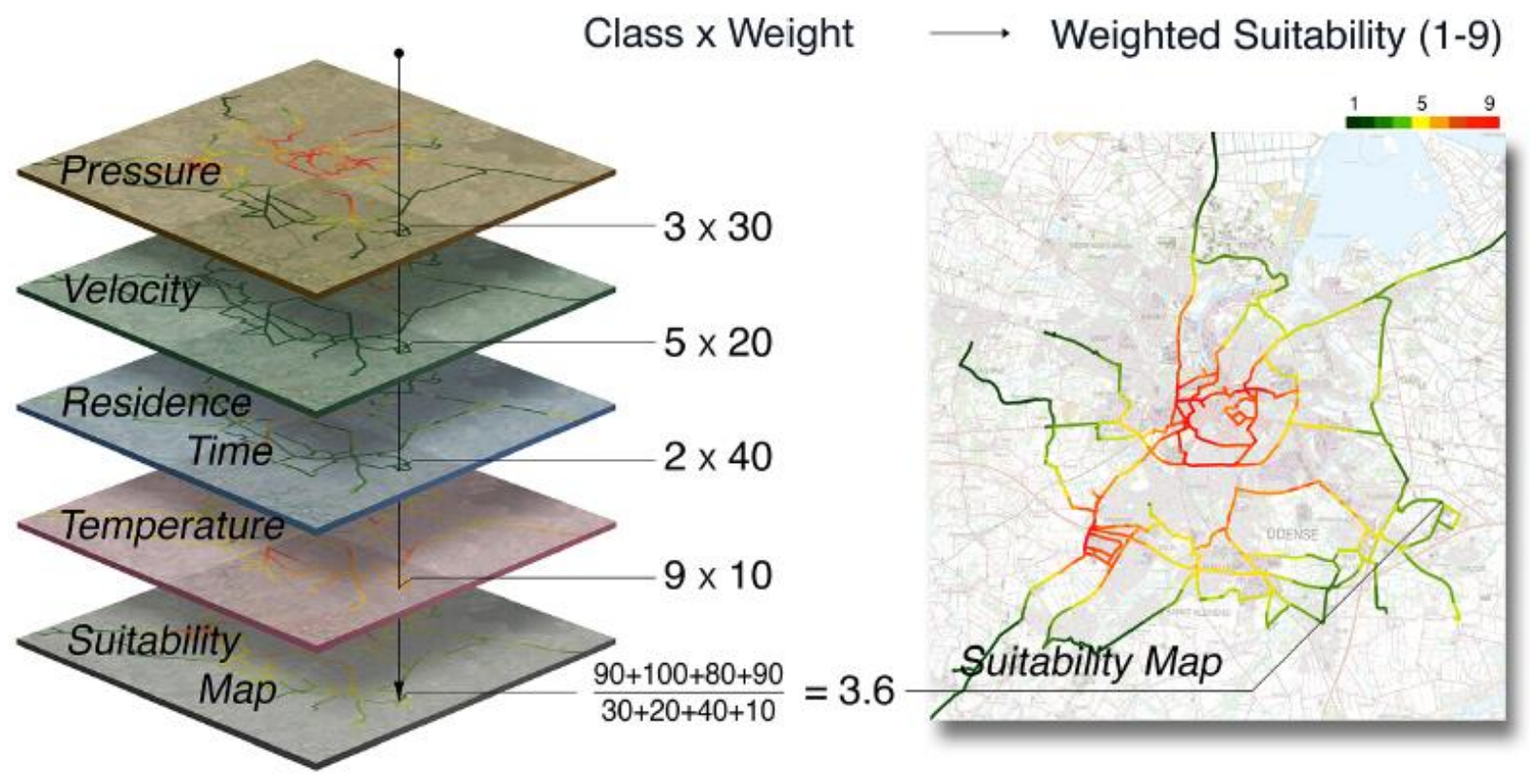

Fig. 1. Identification of suitable water quality monitoring sites, through a six-step approach, using GISbased multi-criteria decision analysis. 


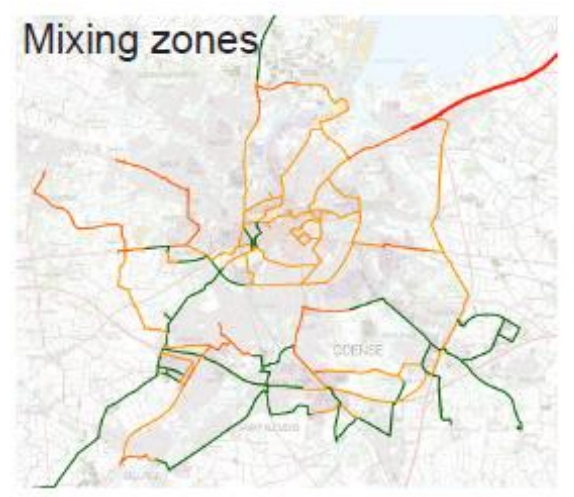

Residence time

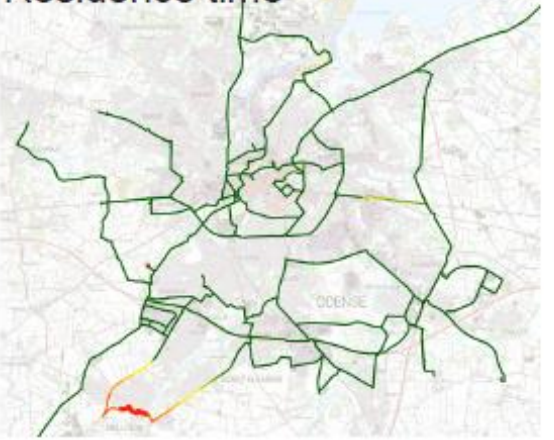

Flooded areas

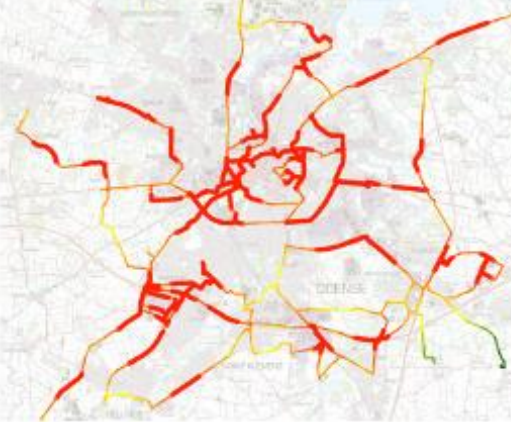

Pipe material

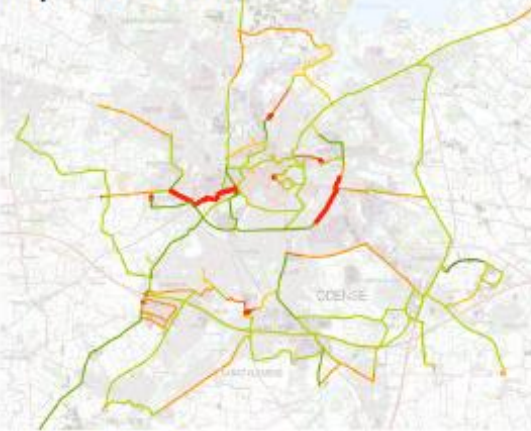

Nursing homes

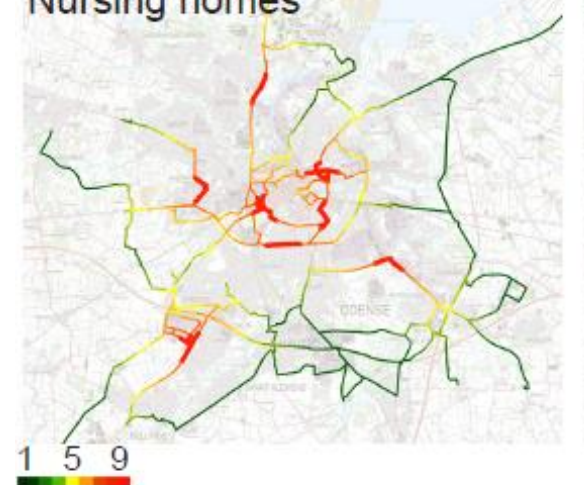

Velocity

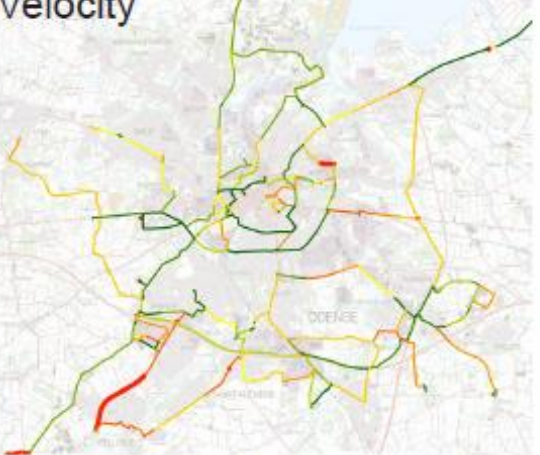

Temperature

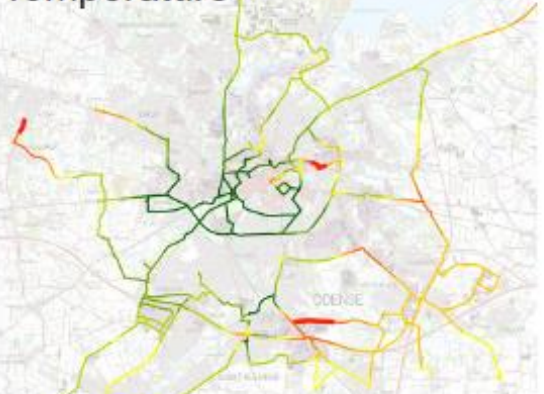

Contaminated sites

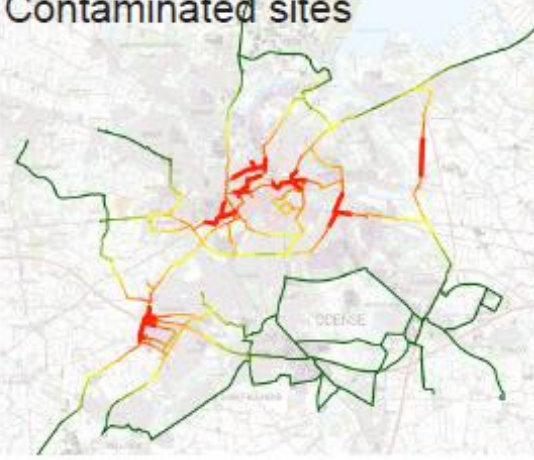

Cross connections

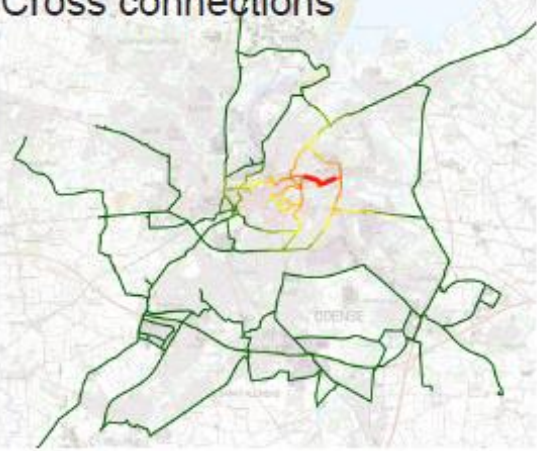

Pressurized waste water pipe Hospitals

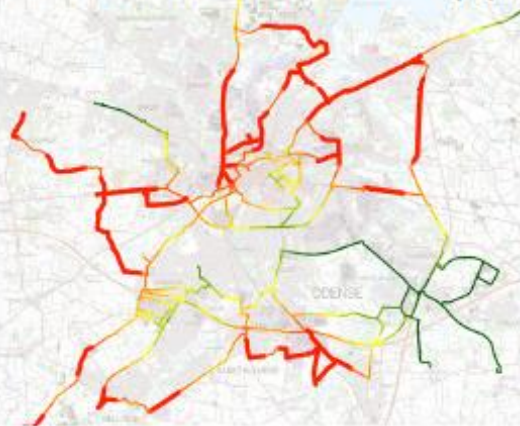

Production cómpanies

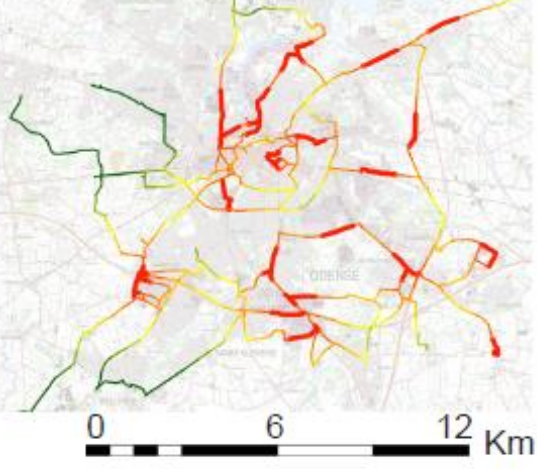

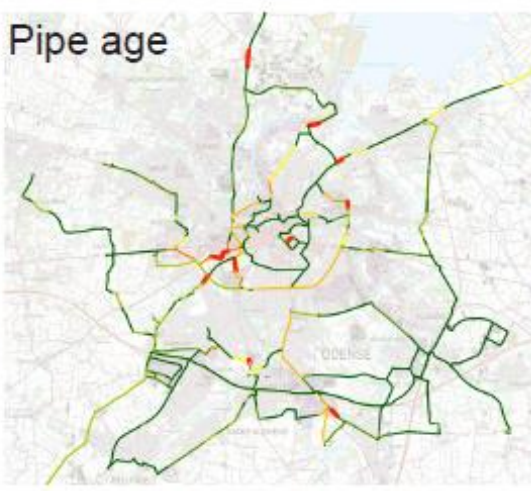

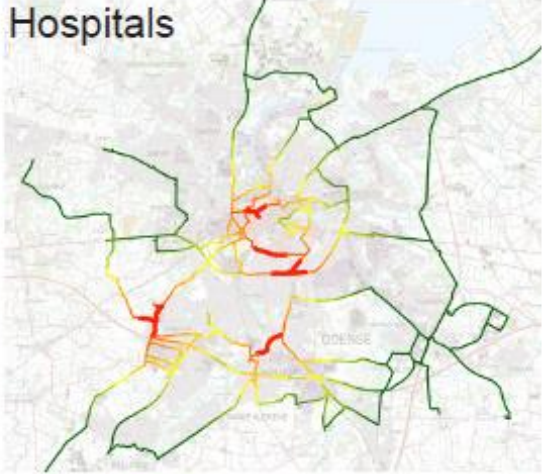


Fig. 2. (Previous side) Suitability maps for individual monitoring site parameters. Data is from VCS Denmark. Green shows pipe segments of low suitability and red shows pipe segments of high suitability for monitoring. 

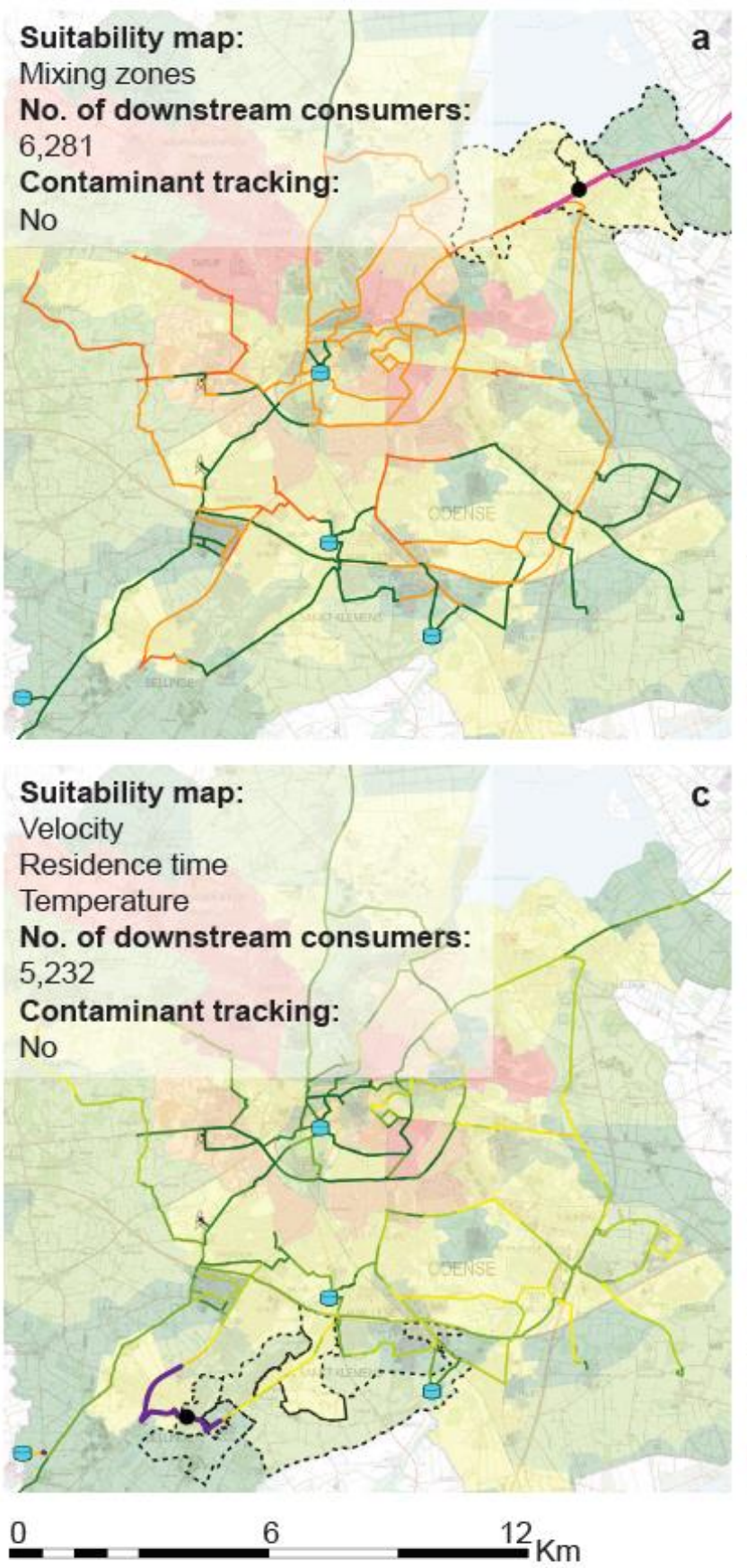

Selected sampling site

\section{Most suitable pipe segments}

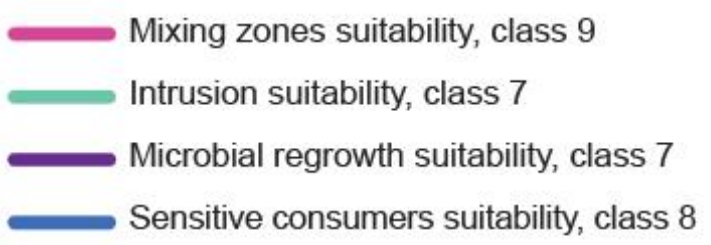

Suitability map:

Pressure

Contaminated sites

Flooded areas

Cross connections

Pipe age

Pipe material

Pressurized wastewater pipes

No. of downstream consumers 8,686

\section{Contaminant tracking:}

No

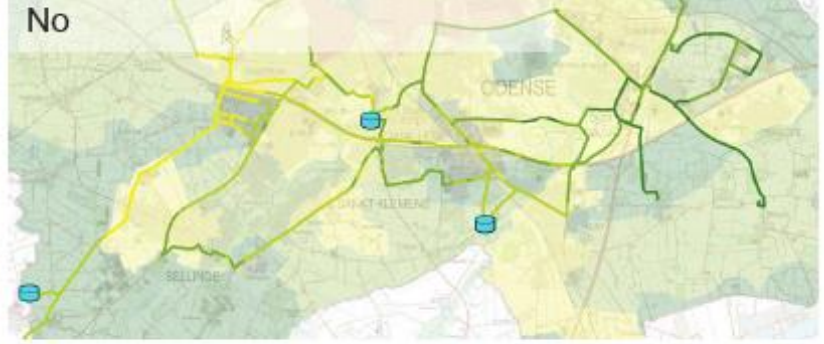

\section{Suitability map:}

Hospitals

Nursing homes

Production companies

No. of downstream consumers:

97,903

Contaminant tracking:

\section{Yes}

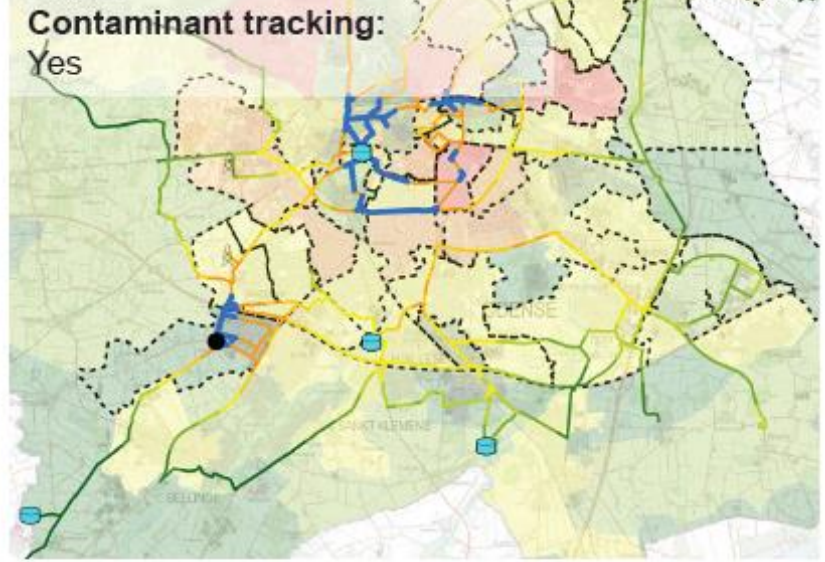

- . - District covered by selected sampling site

E Elevated reservoir

9 Waterworks

\section{Weighted overlay class}

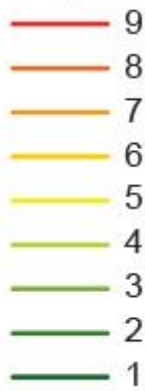

b

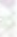


Fig. 3. (Previous side) The most suitable pipe segments for monitoring sites in VCS Denmark according to the groups: Mixing zones (a), intrusion (b), microbial regrowth (c) and sensitive consumers (d).

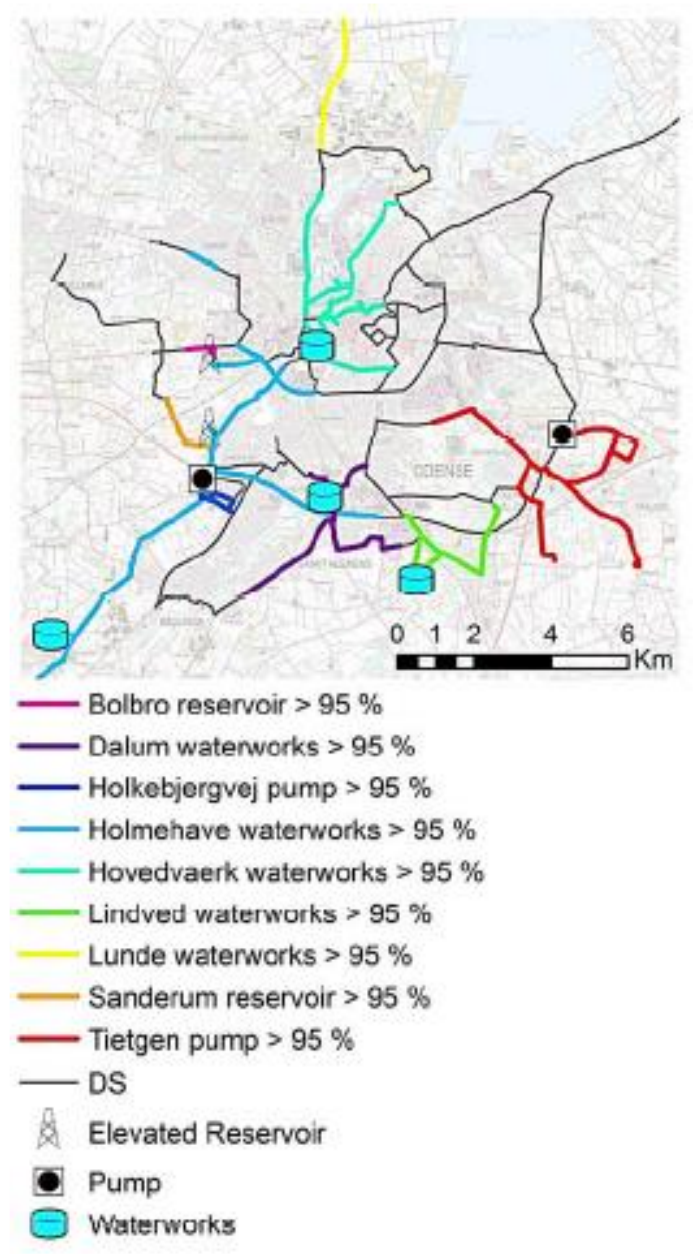

Fig. 4. Contaminant tracking zones, defined by pipe segments where more than $95 \%$ of the water origins from one source in VCS Denmark (eg. Bolbro elevated reservoir). A contaminant released from the source can be tracked in samples taken along those segments. 